\title{
Coder Device
}

National Cancer Institute

\section{Source}

National Cancer Institute. Coder Device. NCI Thesaurus. Code C49876.

A device designed to generate a code. 